STAATSRECHT:

Indonesian Constitutional Law Journal Volume 4 Nomor 1 (2020). P-ISSN: 2549-0915. E-ISSN: 2549-0923

\title{
PEMBATASAN PESERTA PEMILU OLEH KOMISI PEMILIHAN UMUM
}
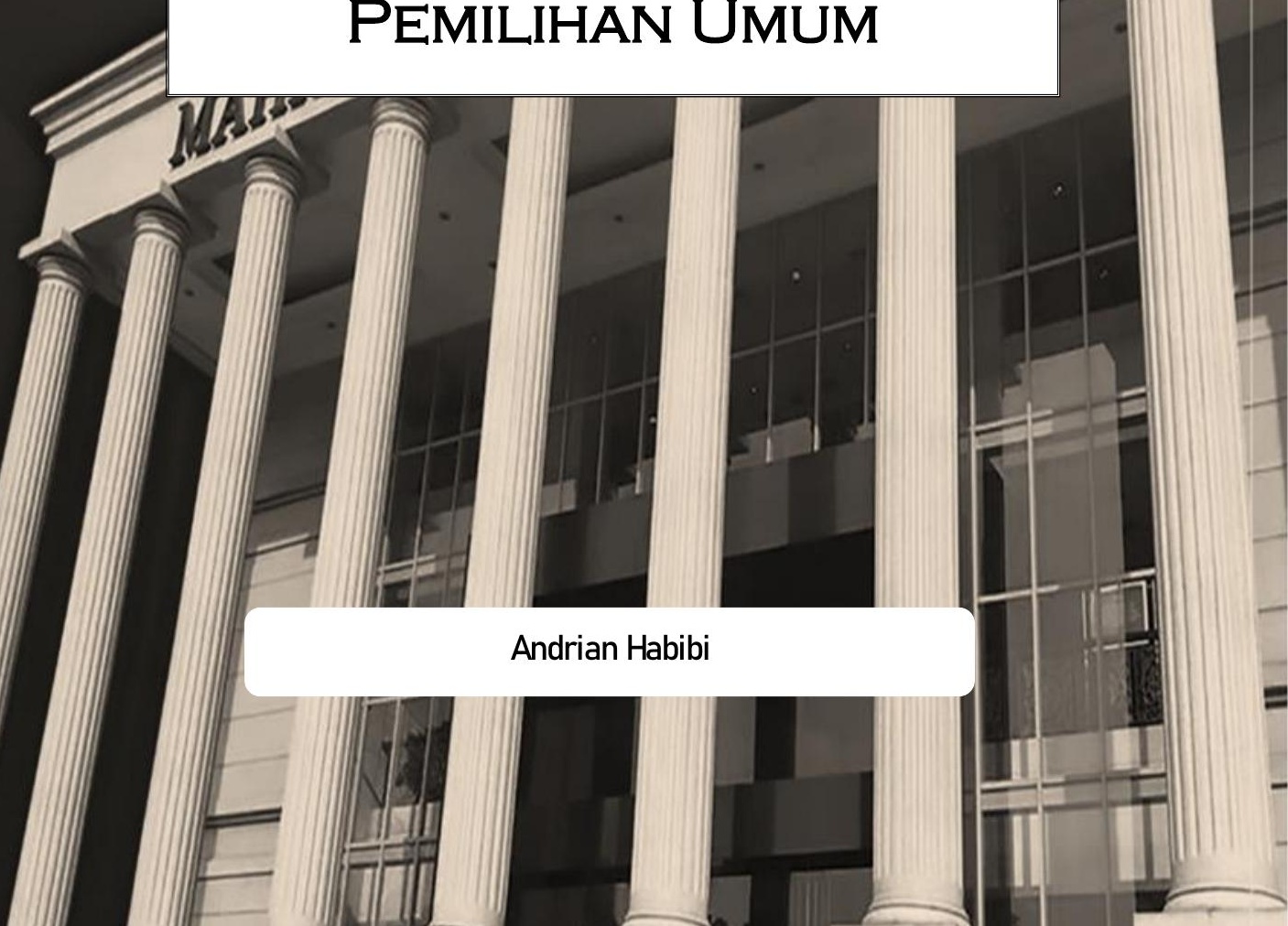


\title{
PEMBatasan PESERTA PEMILU OLEH KOMISI PEMILIHAN UMUM*
}

\author{
Andrian Habibi ${ }^{1}$ \\ Komite Independen Pemantau Pemilu Indonesia
}

doi $10.15408 /$ siclj.v4i1.14549

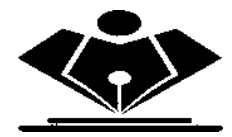

\begin{abstract}
The Election Law instructs election administrators to organize electoral techniques. However, the law regarding the Formation of Legislation said that the discussion and issuance of a rule must refer to the hierarchical concept of legislation. If the technical rules of the election organizer exceed the authority stipulated in the Election Law, then a norm collision will emerge that impacts the norm confusion. This study uses a qualitative narrative study. By explaining the relationship between one legislation and the other. Researchers found the impact of the issuance of PKPU Number 11 in 2017 and the use of Sipol was the death of 13 political parties that registered as candidates for election. In this case, the KPU proved to be a failure, both in maintaining the legality and Sipol application.
\end{abstract}

Keywords: Election Law, Legislative Hierarchy, PKPU, Sipol

* Diterima tanggal 29 Januari 2020, direview tanggal 24 Maret 2020, Publish tanggal 18 Juni 2020.

${ }^{1}$ Anggota Komite Independen Pemantau Pemilu (KIPP) Indonesia. Jln. Cikini I, No. 3, Kel. Cikini, Kec. Menteng, Jakarta Pusat, andrianhabibi@gmail.com. 


\section{A. PENDAHULUAN}

Pemilihan Umum diselenggarakan lima tahun sekali. ${ }^{2}$ Sebelumnya -pemilu pasca reformasi-- Pemilu dibagi atas tiga. Pemilu Presiden dan Wakil Presiden, Pemilu Calon Anggota Legislatif dan Pemilihan Kepala Daerah. Pasca putusan Mahkamah Konstitusi, Pemilu Presiden dan Legislatif diselenggarakan secara serentak. ${ }^{3}$

Setelah Mahkamah Konstitusi memutuskan menetapkan keserentakan pemilu, maka Dewan Perwakilan Rakyat bersama-sama dengan Pemerintah menyusun kodifikasi UU Pemilu. Sepanjang sembilan bulan masa sidang, Panitia Khusus UU Pemilu, maka terbitlah Undang-Undang Nomor 7 Tahun 2017 tentang Penyelenggaraan pemilu. ${ }^{4}$

Dalam penyelenggaraan pemilu, UU memerintahkan penyelenggara pemilu, KPU-Bawaslu-DKPP untuk menyelenggarakan teknis kepemiluan. ${ }^{5}$ Teknis penyelenggaraan pemilu tentu membutuhkan aturan teknis sebagai dasar pelaksanaannya. Karena UU hanya memuat norma umum yang terkadang memerintahkan pelaksana UU untuk memuat aturan turunan secara teknis.

Persoalannya, sesuai dengan Undang-Undang Nomor 12 Tahun 2011 tentang Pembentukan Peraturan Perundangundangan mengatakan pembahasan dan penerbitan suatu aturan harus mengacu kepada konsep hirarkhi peraturan perundang-undangan.

2 Pasal 22E Undang-Undang Dasar Negara Republik Indonesia, Amandemen Keempat.

3 Putusan Mahkamah Konstitusi Nomor 14/PUU-XI/2013 yang dibacakan pada 23 Januari 2014.

4 Lembaran negara Republik Indonesia Tahun 2017 Nomor 182, Undang-Undang Nomor 7 Tahun 2017 tentang Penyelenggaraan Pemilihan Umum, disahkan tanggal 15 Agustus 2017.

5 Titi Anggraini dkk. 2014. Kajian Kodifikasi Undang-Undang Pemilu Penyatuan UU No 32/2004, UU No 12/2008, UU No 42/2008, UU No 15/2011, dan UU No 8/2012, Serta Beberapa Putusan Mahkamah Konstitusi Dalam Satu Naskah, Jakarta: Yayasan Perludem, h.52. 
Hirarki ini adalah urutan atau kasta-kasta dalam peraturan perundang-undangan. Hirarki dibuat agar pembahas, penerbit dan pelaksana UU bisa membahas, menerbitkan dan melaksanakan sesuai dengan tertib hukum. Tertib hukum yang dimaksud adalah norma utama diturunkan ke norma dibawahya dan sebaliknya norma dibawah tidak boleh melebihi norma diatas.

Apabila aturan teknis penyelenggara pemilu melebihi kewenangan yang diatur dalam UU Pemilu. Maka akan muncul tabrakan norma yang berdampak kepada kerancuan norma. Pelaksana teknis seharusnya memuat aturan teknis yang diperintahkan. Tidak memuat norma lain yang berdampak kepada beradunya antara UU dengan peraturan teknis.

Oleh sebab itu, tulisan sederhana ini berusaha menjawab atas beberapa pertanyaan yang bisa berdampak kepada penyelenggaraan pemilu, diantaranya adalah: Bagaimana KPU menerjemahkan UU dalam membahas, menerbitkan dan melaksanakan Peraturan KPU? Bagaimana cara KPU memahami hirarki peraturan perundang-undangan? Bagaimana cara meyelesaikan masalah dari tubrukan antara UU Pemilu dengan PKPU?

\section{B. METODE PENELITIAN}

Penelitian ini menggunakan jenis penelitian yuridis normatif. Penulisan yuridis normatif adalah sebuah penelitian secara kepustakaan yang melalui bahan sekunder. ${ }^{6}$ Sumber data sebagai rujukan penelitian ini menggunakan studi kepustakaan. Penelitian ini menggunakan pendekatan perundang-undangan (statue

6 Romy Hanitijo Soemito, 1998, Metodologi Penelitian Hukum dan Jurimetri, Jakarta: Ghalia Indonesia, h.11. 
approach), pendekatan konsep (conseptual approach), ${ }^{7}$ dan pendekatan komparatif (comparative approach). ${ }^{8}$

\section{ANALISIS DAN PEMBAHASAN}

\section{Hirarki Peraturan Perundang-Undangan}

Undang-Undang adalah aturan yang dibentuk oleh pembentuknya sesuai amanah Konstitusi. Dalam hal ini, Pemerintah dan DPR melaksanakan secara penuh dan menyeleuruh frasa 'bersama-sama'. ${ }^{9}$

Pertama, pembentuk UU melihat pasal demi pasal di UUD NRI 1945. Kedua, setiap pasal yang menganut norma umum dan memiliki penugasan 'selanjutnya dibentuk dalam $U U$ '. Maka pembentuk UU membahas, mengesahkan, menerbitkan UU. Ketiga, UU memerintahkan kepada pelaksana teknis (pemerintah/lembaga pemerintahan) untuk membahas dan menerbitkan aturan teknis pelaksanaan UU.

Dengan demikian, muncul kasta-kasta yang tertib dalam pembentukan peraturan perundang-undangan. Kita mengenal bahasa ini dengan nama Hirarki ${ }^{10}$ Peraturan Perundangundangan yang diatur dalam UU.

7 Peter Mahmud Marzuki, 2005, Penelitian Hukum, Jakarta: Prenadamedia Group, h.133.

8 Abdulkadir Muhammad, 2004, Hukum dan Penelitian Hukum, Bandung: PT. Citra Aditya Bakti, h.113.

9 Setiap rancangan undang-undang dibahas oleh Dewan Perwakilan Rakyat dan Presiden untuk mendapatkan persetujuan bersama. Pasal 20 ayat (2) UUD 1945.

${ }^{10}$ Hirarki menurut Pasal 7 ayat (1) UU No. 12/2011 yaitu adalah penjenjangan setiap jenis peraturan perundang-undangan yang disadarkan pada asas bahwa peraturan perundang-undangan yang lebih rendah tidak boleh bertentangan dengan peraturan perundang-undangan yang lebih tinggi. MukhlisThaib, Dinamika Perundang-undangan di Indonesia. Bandung: Refika Aditama, h.83 
Hirarki peraturan perundang-undangan secara umum disepakati, baik UU maupun pakar, sebagaimana berkut; ${ }^{11} 1$ ). UUD 1945; 2). TAP MPR; 3). UU/Perppu; 4). Peraturan Pemerintah; 5). Peraturan Presiden; 6). Perda Provinsi; 7). Perda $\mathrm{Kab} /$ kota. Jadi, dalam kepemiluan hirarki peraturan perundang-undangannya, sebagai berikut: 1). UUD 1945; 2). UU No. 7 Tahun 2017; 3). PKPU, Perbawaslu dan Peraturan DKPP; 4). SK; 5). SE.

Bagir Manan menyebutkan bahwa dalam hirarki peraturan perundang-undangan, terdapat tertib hukum. Maksudnya adalah sebuah peraturan harus mengikuti derajat aturan sehingga muncul keserasian dan saling menguatkan antar aturan.

Dalam ajaran Bagir Manan, Hirarki peraturan perundang-undangan dibahas sesuai dengan prinsip dan asasasas hukum. Kepentingan prinsip adalah menjamin tertib hukum terlaksana mulai dari proses pembahasan sampai pelaksanaan peraturan perundang-undangan. ${ }^{12}$

Asas hukum menganut teori-teori hukum yang berlaku secara umum. Adapun asas tersebut bisa kita jelaskan berikut ini :

Lex posterior derogat lex priori adalah dalam hal pertentangan peraturan perundang-undangan dengan peraturan perundangundangan sederajat lainnya, maka berlaku peraturan perundang-undangan yang terbaru dan peraturan perundangundangan lama dianggap telah dikesampingkan.

Lex superior derogat lex inferiori adalah dalam hal peraturan perundang-undangan yang lebih tinggi tingkatnya bertentangan dengan peraturan perundang-undangan yang lebih rendah, maka berlaku peraturan perundang-undangan yang lebih tinggi tingkatannya.

11 Pasal 7 UU No. 12 Tahun 2011 tentang Pembentukan Peraturan Perudang-Undangan

12 Bagir Manan, Dasar-Dasar Perundang-Undangan Indonesia, Ind-Hill. Co, Jakarta, 1992, hlm 14-15, baca juga: Mukhlis Thaib, 2017. Dinamika Perundang-undangan di Indonesia. Bandung: Refika Aditama, h.39. 
Lex specialis derogat lex generalis adalah dalam hal peraturan perundang-undangan yang mengatur bidang-bidang yang merupakan kekhususan dari bidang-bidang umum yang diatur oleh peraturan yang sederajat, maka berlaku peraturan perundang-undangan yang mengatur bidang khusus tersebut.

\section{Tidak Tertib Mengancam Teknis}

KPU sebagai pelaksana teknis yang tetap, mandiri dan profesional ditugas juga mengatur secara detil teknis penyelenggaraan pemilu. Peraturan ini disebut dengan PKPU. Lahirnya PKPU adalah bentuk perintah UU yang menggunakan kalimat 'selanjutnya diatur dalam PKPU' dan 'selanjutnya diatur dengan PKPU'.

Dengan demikian, PKPU layaknya UU yang dibahas, disahkan dan dilaksanakan atas perintah aturan yang lebih tinggi. Sehingga KPU tidak bisa memuat aturan yang lebih tinggi di PKPU daripada norma yang termuat di UUD, TAP MPR dan UU Pemilu.

Hal ini dikarenakan KPU adalah pelaksana teknis. Jika dilihat kembali hirarkhi peraturan perundang-undangan. KPU hanya bisa memuat aturan yang diturunkan secara tertib mulai dari UUD 1945 ke UU Pemilu. Lalu menerbitkan PKPU yang merupakan turunan secara tekis dari UU Pemilu.

Agar lebih jelas, maka dapat dilihat masalah ketidaktertiban KPU dalam menyusun dan melaksanakan PKPU.

Sebagaimana diketahui, KPU telah menerbitkan 12 Peraturan KPU tahun 2017.13 Tujuannya adalah sebagai dasar teknis peyelenggaraan pemilu yang diperintahkan UU. Namun, muncul perdebatan terkait norma yang hadir di PKPU Nomor 11 Tahun 2017 tetang Pendaftaran, Verfikasi dan Penetapan Partai Politik Peserta Pemilihan Umum Anggota Dewan Perwakilan Rakyat dan Dewan Perwakilan Rakyat Daerah.

${ }^{13}$ Jdih.kpu.go.id/peraturan-kpu 
Apa yang penulis maksud adalah munculnya norma 'wajib' pada Sistem Informasi Partai Politik calon peserta pemilu. Pasal 13 ayat (1) PKPU 11/2017 menyatakan bahwa setiap partai politik yang mendaftar ke KPU diwajibkan mengisi Sipol. Nah, Sipol ini menjadi masalah terkait norma dan fungsinya.

Secara norma, Sipol tidak diatur dalam UU D 1945 dan UU Pemilu. Sehingga, munculnya norma Sipol di PKPU menjadi bentuk perluasan kewenangan KPU. Memang benar KPU adalah penerbit aturan teknis dan pelaksana teknis. Tetapi, KPU harus menerbitkan PKPU dan melaksanakannya sesuai dengan perintah UU.

Jika kembali kepada ajaran tertib hukum pada hirarki peraturan perundang-undangan, maka PKPU dalam hal ini telah memuat aturan khusus yang melebihi kewenangan aturan umum diatasnya. UU Pemilu hanya memerintahkan KPU untuk menerima pendafataran peserta pemilu, memeriksa (meneliti) kelengkapan administrasi, melakukan verfikasi faktual lalu menetapkan peserta pemilu tahun 2019. Sehingga, Sipol bukanlah alat untuk KPU untuk memperluas kewenangannya yang tidak diatur dalam UU. Dalam pemahaman sederhana, pendaftaran adalah penerimaan berkas dengan melihat kelengkapan sesuai dengan syarat pendaftaran yang diatur oleh UU dan PKPU, tidak lebih dari hal itu.

Dengan demikian, PKPU 11 tahun 2017 seharusnya 'batal demi hukum'. Kenapa? Karena PKPU memuat aturan yang tidak tertib hirarki atau kasta hukum. Akibat ketidaktertiban ini, maka berlakulah lex generalis derojat lex spesialis, bahwa aturan umum lebih tinggi dari aturan khusus. Secara langsung PKPU batal dan tidak bisa dipakai untuk menegaskan keberadaan Sipol sebagai verifikator pendaftaran calon peserta pemilu.

Masalah kedua berkenaan dengan fungsi Sipol sesuai PKPU 11/2017. KPU menggunakan kata 'wajib' demi menegaskan keberadaan Sipol. Jadi, Sipol bisa dipakai sebagai alat penyeleksi awal calon peserta pemilu. 
Padahal, Sipol hadir untuk memverfikasi keabsahan syarat pendaftaran peserta pemilu. Khairul Fahmi menegaskan bahwa Sipol seharusnya berlaku pada saat tahapan penelitian administrasi (paska pendaftaran). Karena Sipol adalah sistem informasi partai politik yang berisi data-data administrasi.

Dalam pemahaman wajar, alat verifikasi berlaku saat verifikasi dilaksanakan, bukan sebelum atau sesudah. Sehingga tujuan Sipol melakukan pengecekan data atau keabsahan setiap berkas. Sejatinya dalam rumpus pelaksana teknis, para pendaftar membawa berkas administrasi. Lalu KPU menerima pendaftaran parpol. Setelah itu, Sipol bekerja untuk memeriksa keabsahan berkas. Akan tetapi, perlu diingat bahwa Sipol sebagai alat verifikasi penelitian keabsahan syarat calon peserta pemilu tidak wajib dan tidak menggugurkan pendaftar. KPU dengan Sipolnya mengingatkan berkas-berkas apa yang harus dilengkapi akibat kerja Sipol menolak beberapa berkas. Jadi, tidak tepat Sipol secara ranah teknis diletakkan pada tahapan pendaftaran. Sesuai dengan alasan lahir atau tujuan lahirnya, Sipol seharusnya berada di tahapan penelitian administrasi sesuai dengan pemamfaatannya. Sehingga tidak membutuhkan frasa 'wajib' di PKPU.

\section{Masalah Bermunculan}

Dampak dari penerbitkan PKPU 11/2017 dan penggunaan Sipol adalah gugurnya 13 partai politik yang mendaftar sebagai calon peserta pemilu. Tentu saja ini bukan karena salah Sipolnya. Penyebab lain adalah keterlambatan dan ketidaksiapan 13 parpol untuk mendaftar dengan kelengkapan berkas beserta kemampuan mengisis Sipol sesuai berkas yang ada.

Namun, sebagai pelaksana teknis pemilu, KPU seharusnya melihat titik lemah penggunaan Sipol. Akibat ketidaksiapan parpol, bahkan KPU pada tanggal 16 Oktober 2017 atau hari terakhir pendafaran calon peserta pemilu terpaksa mengeluarkan Surat Edaran Nomor 585 Tahun 2017 tentang perpanjangan masa input data Sipol. 
Surat Edaran Nomor 585 jelas akal-akalan yang dibuat akibat kepanikan pemamfaat Sipol. Niat awal Sipol bisa mempermudah pemberkasan. Ternyata Sipol menyusahkan dan membuat 13 partai kehilangan hak konstitusionalnya untuk mengikuti tahapan pemilu. Muncul kekacauan hukum pemilu yang dibenturkan dengan asas adil, profesional dan proporsional penyelenggara pemilu. Selain itu, KPU mendapati masalah lain yakni tidak memberikan kepastian hukum kepada semua pihak. KPU tidak menyatakan dengan jelas partai yang lolos dan tidak lolos pendaftaran. Kita hanya melihat KPU mengumumkan di portal dan media sosialnya terkait partaipartai yang lolos dan tidak lolos pendaftaran. Padahal, sebab musabab harus pasti, kalau KPU menyatakan sikap. Tentu saja sikap itu terbukti pada berkas Surat Keputusan atau Berkas Acara penerimaan berkas, penginputan data Sipol dan penetapan peserta lolos atau tidak dalam tahapan pendaftaran. Berkas ini harus dikeluarkan oleh KPU mengingat fungsinya sebagai bukti teknis dan alasan legal bagi pendaftar.

Penulis menilai bahwa KPU tidak menegakkan keadilan bagi setiap orang, termasuk partai politik. Dengan demikian, KPU harus menerima empat gugatan secara langsung. Pertama, 13 parpol mendaftarkan gugatan ke Bawaslu untuk memperoleh keadilan yang sama sebagai calon peserta pemilu. Bawaslu dengan kewenangan yang diperkuat, salah satu memeriksa dan mengadili sengketa administrasi (walaupun tidak berhubungan dengan verifikasi partai dalam UU Pemilu) dapat merekomendasikan agar KPU mengikutsertakan 13 parpol dalam tahapan penelitian administrasi dan verifikasi faktual. Akibat putusan Bawaslu, maka KPU dinyatakan tidak adil, tidak tertib, tidak profesional dan sebagainya. Akan tetapi, sebelum membawa masalah asas pemilu kepada DKPP, maka peserta bisa mengambil jalur hukum kedua dan ketiga, yakni memasukkan gugatan ke PTUN dan MK.

Apabila PTUN dan MK memenangkan gugatan 13 partai politik. Dengan demikian, tiga putusan bisa memperkuat alasan gugatan terakhir yang ditujukan ke DKPP. Sehingga, 
putusan DKPP seharusnya bisa diprediksi yaitu menyatakan komisioner telah melanggar asas pemilu dan dinyatakan tidak berintegritas. Dengan demikian, DKPP bisa memberhentikan keseluruhan atau sebahagian komisioner KPU.

\section{KESIMPULAN}

Peraturan perundang-undangan dibuat untuk mengatur kehidupan manusia agar lebih tertib. Peraturan juga menjaga lembaga menjalankan amanah konstitusi untuk mengerjakan pekerjaannya. Dalam ilmu hukum, peraturan perundangundangan mengenal tata tingkatan atau hirarki peraturan perundang-undangan. Hirarki ini menjamin norma dasar yang terkandung dalam konstitusi bisa diteruskan sampai aturan terendah. Dalam rezim pemilu, hirarki peraturan perundangundangan bisa disebut secara berturut; UUD 1945, UU Pemilu dan PKPU/Perbawaslu/Peraturan DKPP. Dengan prinsip bahwa aturan teknis yang dikeluarkan oleh penyelenggara pemilu tidak boleh bertentangan dengan UU Pemilu. Begitu juga UU Pemilu tidak boleh bertentangan dengan UUD 1945.

KPU RI telah menerbitkan 12 PKPU pada tahun 2017, akan tetapi lembaga ini butuh penguatan bidang kajian dan hukum. Hal ini mengingat masalah hukum yang diakibatkan oleh PKPU 11/2017 tentang Pendaftaran, Verifikasi dan Penetapan Parpol Peserta Pemilu.

Dengan demikian, penulis menyarankan kepada KPU untuk menyerahkan proses pembahasan PKPU kepada biro hukum dan kajian tanpa ada intervensi. Setelah itu, draft PKPU bisa diharmonisasikan dengan PKPU yang lama pada pemilupemilu sebelumnya untuk penyempurnaan. Selain itu, hendaknya KPU mempertimbangkan kepastian hukum dalam menerbitkan PKPU. Apabila dinilai atau ada masukan terkait kelemahan suatu PKPU, maka sewajarnya KPU melakukan revisi dan menerbitkan ulang PKPU yang telah mendapatkan masukan, saran dan kritik. KPU juga perlu untuk melakukan kodifikasi PKPU untuk menyelesaikan kekosongan hukum 
suatu teknis penyelenggaraan. Kodifikasi PKPU ini dengan cara menghimpun seluruh PKPU yang ada dan menyesuaikan dengan UU Pemilu terbaru.

\section{REFERENSI:}

Aji, A.M.; Yunus, N.R. 2018. Basic Theory of Law and Justice, Jakarta: Jurisprudence Institute.

Anggraini, Titi. dkk. Kajian Kodifikasi Undang-Undang Pemilu Penyatuan UU No 32/2004, UU No 12/2008, UU No 42/2008, UU No 15/2011, dan UU No 8/2012, Serta Beberapa Putusan Mahkamah Konstitusi Dalam Satu Naskah, Jakarta: Yayasan Perludem.

Jdih.kpu.go.id/peraturan-kpu

Lembaran negara Republik Indonesia Tahun 2017 Nomor 182, Undang-Undang Nomor 7 Tahun 2017 tentang Penyelenggaraan Pemilihan Umum, disahkan tanggal 15 Agustus 2017

Maggalatung, A.S.; Aji, A.M.; Yunus, N.R. 2014. How The Law Works, Jakarta: Jurisprudence Institute.

Manan, Bagir. 1992. Dasar-Dasar Perundang-Undangan Indonesia, Jakarta: Ind-Hill. Co.

Putusan Mahkamah Konstitusi Nomor 14/PUU-XI/2013 yang dibacakan pada 23 Januari 2014

Thaib, Mukhlis. 2017. Dinamika Perundang-undangan di Indonesia. Bandung: Refika Aditama.

Undang-Undang Dasar Negara Republik Indonesia, Amandemen Keempat

Yunus, N.R.; Anggraeni, RR Dewi.; Rezki, Annissa. 2019. "The Application of Legal Policy Theory and its relationship with Rechtsidee Theory to realize Welfare State," 'Adalah, Volume 3, No. 1. 